Article

\title{
Degradation of Four Major Mycotoxins by Eight Manganese Peroxidases in Presence of a Dicarboxylic Acid
}

\author{
Xiaolu Wang ${ }^{1,+}$, Xing Qin ${ }^{1,2,+}$, Zhenzhen Hao ${ }^{1}$, Huiying Luo ${ }^{1}$, Bin Yao ${ }^{1, *}$ and Xiaoyun Su ${ }^{1, *}$ \\ 1 Key Laboratory for Feed Biotechnology of the Ministry of Agriculture, Feed Research Institute, Chinese \\ Academy of Agricultural Sciences, Beijing 100081, China; xiaolu4444@126.com (X.W.); \\ xingqin@hust.edu.cn (X.Q.); zhenzhenhao2012@163.com (Z.H.); luohuiying@caas.cn (H.L.) \\ 2 College of Life Science and Technology, Huazhong University of Science and Technology, \\ Wuhan 430074, China \\ * Correspondence: binyao@caas.cn (B.Y.), suxiaoyun@caas.cn (X.S.); Tel.: +86-10-8210-6094 (X.S.) \\ + These authors contribute equally to this work.
}

Received: 27 August 2019; Accepted: 26 September 2019; Published: 27 September 2019

check for updates

\begin{abstract}
Enzymatic treatment is an attractive method for mycotoxin detoxification, which ideally prefers the use of one or a few enzymes. However, this is challenged by the diverse structures and co-contamination of multiple mycotoxins in food and feed. Lignin-degrading fungi have been discovered to detoxify organics including mycotoxins. Manganese peroxidase $(\mathrm{MnP})$ is a major enzyme responsible for lignin oxidative depolymerization in such fungi. Here, we demonstrate that eight MnPs from different lignocellulose-degrading fungi (five from Irpex lacteus, one from Phanerochaete chrysosporium, one from Ceriporiopsis subvermispora, and another from Nematoloma frowardii) could all degrade four major mycotoxins (aflatoxin $\mathrm{B}_{1}, \mathrm{AFB}_{1}$; zearalenone, $\mathrm{ZEN}$; deoxynivalenol, DON; fumonisin $\mathrm{B}_{1}, \mathrm{FB}_{1}$ ) only in the presence of a dicarboxylic acid malonate, in which free radicals play an important role. The I. lacteus and C. subvermispora MnPs behaved similarly in mycotoxins transformation, outperforming the P. chrysosporium and N. frowardii MnPs. The large evolutionary diversity of these MnPs suggests that mycotoxin degradation tends to be a common feature shared by $\mathrm{MnPs}$. MnP can, therefore, serve as a candidate enzyme for the degradation of multiple mycotoxins in food and feed if careful surveillance of the residual toxicity of degradation products is properly carried out.
\end{abstract}

Keywords: manganese peroxidase; mycotoxin; aflatoxin; zearalenone; deoxynivalenol; fumonisin; detoxification

Key Contribution: MnP may serve as a candidate enzyme for the degradation of multiple mycotoxins. Interaction of $\mathrm{MnP}$ with malonate and consequently the generated free radicals play an important role in mycotoxins degradation. RB5 decolorization may serve as a starting point to dictate discovery of novel mycotoxin-degrading MnPs.

\section{Introduction}

Mycotoxins are a diverse, large group of fungal secondary metabolites that exert severe toxic effects on human and animals worldwide. A recent study revealed that, among the nearly 20,000 feed and feed raw material samples which were collected from Asia, Europe, Americas, Africa, and Middle East, $72 \%$ contained at least one of the five major mycotoxins (aflatoxin $\mathrm{B}_{1}, \mathrm{AFB}_{1}$; zearalenone, $\mathrm{ZEN}$; deoxynivalenol, DON; fumonisin $\mathrm{B}_{1}, \mathrm{FB}_{1}$; and ocharatoxin $\mathrm{A}, \mathrm{OTA}$ ). See Figure 1 for structures [1]. 
In the United States, an annual loss of $\$ 52.1$ million to $\$ 1.68$ billion is estimated to be caused by merely aflatoxin contamination in the corn industry [2].<smiles>COc1cc2c([C@H]3C=CO[C@@H]3O)c3c1C1=C(C(=O)CC1)[C@H]3C=CO2</smiles>

$\mathrm{FB}_{1}$

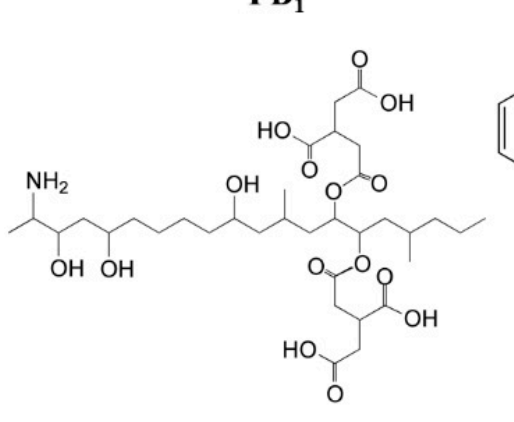

ZEN<smiles>C[C@H]1CCCCC(=O)CCC/C=C/c2cc(O)cc(O)c2C(=O)O1</smiles>

OTA

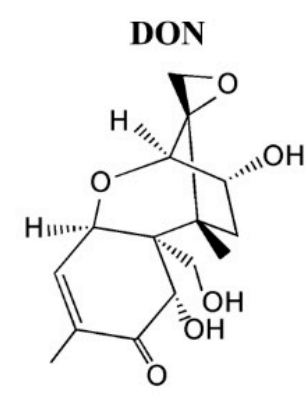

RB5

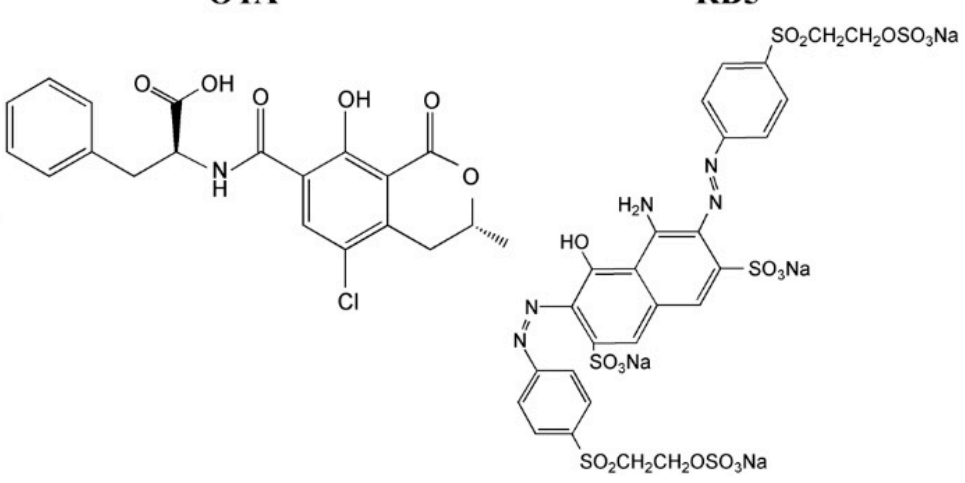

Figure 1. The chemical structures of five major mycotoxins (aflatoxin $\mathrm{B}_{1}\left(\mathrm{AFB}_{1}\right)$, zearalenone (ZEN), deoxynivalenol (DON) fumonisin $\mathrm{B}_{1}\left(\mathrm{FB}_{1}\right)$, ocharatoxin $\mathrm{A}(\mathrm{OTA})$ ) and the synthetic dye RB5. The highlighted part in blue is a coumarin structure, which is a derivative of the lignin monomer p-coumaryl alcohol.

To minimize mycotoxin contamination, agronomic means have proven to be effective in reducing the risk but are still inadequate [1]. Physical and chemical treatments of food and feed do not remove mycotoxins effectively because these secondary metabolites are often insensitive. In feed industry, inert adsorbents such as montmorillonite are widely used to bind mycotoxins in the animal's gastrointestinal tract. However, binding of mycotoxins to adsorbents is effective for only limited kinds of mycotoxins such as $\mathrm{AFB}_{1}$ because of the inherent selective nature of adsorbents [3]. Therefore, microbial and, in essence, enzymatic detoxification are increasingly regarded as an attractive method to control mycotoxin contamination. However, mycotoxins are structurally distinct to each other and, more importantly, different types of mycotoxins usually co-exist in the food, feed, and feed raw materials. For example, more than $38 \%$ of the samples were detected with co-contamination of two or even more mycotoxins [1]. To deal with the complexity of mycotoxin contamination, a feasible route toward economic detoxification would ideally be to use one or a few enzymes. This requires that enzymes must have a wide substrate specificity on multiple mycotoxins.

Most of the identified enzymes that are able to detoxify mycotoxins can be grouped into hydrolase, transferase, epimerase, and oxidoreductase. Although most discovered enzymes, if not all, are reported to detoxify only a certain type of mycotoxins, among the oxidoreductases, a special group of enzymes targeting lignin (i.e., laccase and lignin-modifying peroxidases) have intriguing promiscuous substrate specificity. It is thus noted that the lignin-degrading white rot fungi have been successfully used in mycotoxin detoxification [4,5]. In addition, part of mycotoxins may be structurally similar to a lignin monomer or its derivatives. For example, $\mathrm{AFB}_{1}$ has a coumarin structure (Figure 1), which is a derivative of the lignin monomer $p$-coumaryl alcohol [6]. Indeed, laccase (a multicopper oxidase catalyzing lignin degradation or polymerization) [7] and manganese peroxidase ( $\mathrm{MnP}, \mathrm{a} \mathrm{Mn}{ }^{2+}$-dependent lignin-degrading peroxidase) [8] are occasionally found to be able to degrade 
$\mathrm{AFB}_{1}[9-11] . \mathrm{MnP}$ has a higher redox potential than laccase, suggestive of its higher ability to react with more recalcitrant substrates. $\mathrm{MnP}$ is widely distributed in lignin-degrading white-rot filamentous fungi. However, despite the previous finding of $\mathrm{MnP}$ to degrade $\mathrm{AFB}_{1}$, it remains unknown if $\mathrm{MnP}$ can serve as a candidate enzyme to degrade multiple mycotoxins. In this study, we determined the ability of $\mathrm{MnP}$ to act on other mycotoxins and if the ability to degrade multiple mycotoxins is a feature shared by MnPs. The recombinantly produced MnPs used in this study were from Irpex lacteus CD2, Phanerochaete chrysosporium, and Ceriporiopsis subvermispora. All these fungi have not been reported to have mycotoxin-degrading ability. However, they all express MnPs involved in lignin degradation. I. lacteus CD2 encodes seven MnPs [12], with two of them having the ability to oxidize the recalcitrant non-phenolic lignin model compound veratryl alcohol in the presence of malonate [13]. P. chrysosporium and C. subvermispora are the representative simultaneous and selective white rot lignocellulose degraders, respectively [14], both of which also encode $\mathrm{MnP}$ enzymes [15,16]. Therefore, five MnPs from I. lacteus $\mathrm{CD} 2$ (which can be recombinantly produced) and one each representative $\mathrm{MnP}$ from P. chrysosporium and C. subvermispora were tested for their ability to degrade multiple mycotoxins.

\section{Results}

\subsection{Degradation of $A F B_{1}$ and $\mathrm{ZEN}$ by IIMnP5 and IlMnP6}

$\mathrm{MnPs}$, frequently discovered in white rots, have a higher redox potential (up to $1.5 \mathrm{~V}$ ) than laccase (up to $790 \mathrm{mV}$ ) [17,18]. Moreover, certain carboxylates, such as malonate, can further boost the ability of MnPs to oxidize chemicals with even higher redox potentials or more recalcitrant structures [13]. In addition to $\mathrm{AFB}_{1}, \mathrm{ZEN}$ is also a common mycotoxin contaminant of food or feed. Therefore, we started to investigate if $\mathrm{MnP}$ can degrade multiple mycotoxins by using $\mathrm{ZEN}$ in addition to $\mathrm{AFB}_{1}$ as the two most common mycotoxins in such a malonate buffer.

I. lacteus is known to encode seven MnP enzymes, among which IlMnP5 and IlMnP6 are the easiest to produce recombinantly. Therefore, IlMnP5 and IlMnP6, the two I. lacteus MnPs recombinantly produced in E. coli, were first tested for their ability to degrade $\mathrm{AFB}_{1}$ and $\mathrm{ZEN}$, the two major mycotoxins with much differing chemical structures (Figure 1). The activities of the two enzymes were calibrated using 2,2'-Azino-bis(3-ethylbenzothiazoline-6-sulphonic acid (ABTS) as the substrate. The enzymes $\left(0.5 \mathrm{U} / \mathrm{mL}\right.$ each) were individually incubated with $5 \mu \mathrm{g} / \mathrm{mL}$ each of $\mathrm{AFB}_{1}$ or $\mathrm{ZEN}$ in $70 \mathrm{mM}$ malonate buffer supplemented with $1 \mathrm{mM} \mathrm{MnSO}_{4}$ and $0.1 \mathrm{mM} \mathrm{H}_{2} \mathrm{O}_{2}$. The reaction was carried out at $30^{\circ} \mathrm{C}$ for $9 \mathrm{~h}$. Periodically, samples were taken out and three volumes of DMSO were added to terminate the reaction. HPLC was used to analyze the reaction products. It was thus discovered that degradation of $\mathrm{AFB}_{1}$ was fast for both enzymes (Figure 2a). The degrading percentages were $50.7 \%$ and $49.3 \%$ after $30 \mathrm{~min}$, increased steadily to $84.9 \%$ and $83.7 \%$ at the end of $3 \mathrm{~h}$, and then gradually ascended to $94.6 \%$ and $94.5 \%$ for $I l \mathrm{MnP} 5$ and $I l \mathrm{MnP} 6$, respectively, after $9 \mathrm{~h}$. The degradation of ZEN was slower, with degradation percentages of $34.0 \%$ and $33.2 \%$ for $I l \mathrm{MnP} 5$ and IlMnP6, respectively, at $9 \mathrm{~h}$ (Figure $2 \mathrm{~b}$ ).

To have a first glimpse if $\mathrm{AFB}_{1}$ degradation may lead to detoxification, growth of hydra was inspected in a culture containing $\mathrm{AFB}_{1}$ treated or non-treated with one of the MnPs. Hydra has been used to determine the residual toxicity of $\mathrm{AFB}_{1}$ treated with ozone [19]. The hydra shrunk at $20 \mathrm{~h}$ and finally collapsed $\left(40 \mathrm{~h}\right.$ ) when incubated with non-treated $\mathrm{AFB}_{1}$ (Figure 2c). In contrast, they remained alive even after $40 \mathrm{~h}$ of incubation in either of the MnPs-treated $\mathrm{AFB}_{1}$ samples. For ZEN, an assay using an engineered S. cerevisiae strain BLYES was employed. With an estrogenic activity, ZEN can bind to an intracellular estrogen receptor and stimulate emission of bioluminescence in this yeast (Figure S1) [20,21]. BLYES was thus grown to an optical density of 0.6 and incubated for $6 \mathrm{~h}$ with MnPs-treated ZEN. As a control, non-treated ZEN was diluted to a concentration at the mid-log phase of the responsive curve (Figure S1), allowing the most sensitive detection of ZEN degradation. Although only $33.2 \%$ of ZEN was degraded after $9 \mathrm{~h}$ of incubation, at the same dilution fold, the bioluminescence in the MnP-treated ZEN samples were significantly decreased to $10.6 \%$ (IlMnP5) 
and 14.2\% (IlMnP6) (Figure 2d), which is consistent with the responsive curve. This indicated that enzymatic treatment by both MnPs largely mitigated the estrogenicity of ZEN (Figure 2d). From these experiments, a preliminary impression was deduced that the action of IlMnP5 and IlMnP6 may lead to detoxification of the $\mathrm{AFB}_{1}$ and $\mathrm{ZEN}$ mycotoxins with these model systems.

(a)

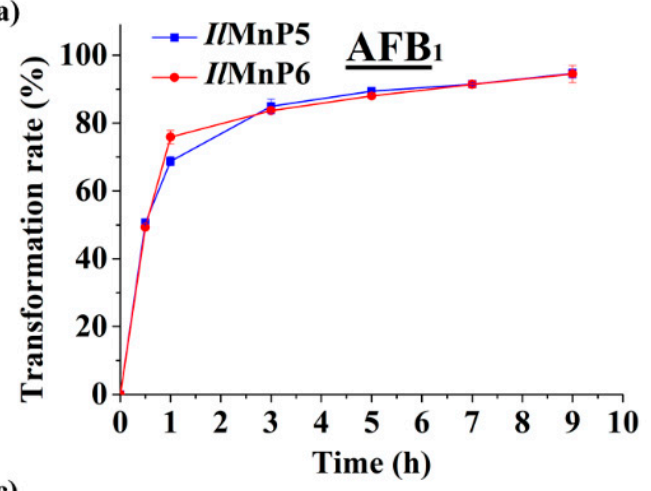

(c)

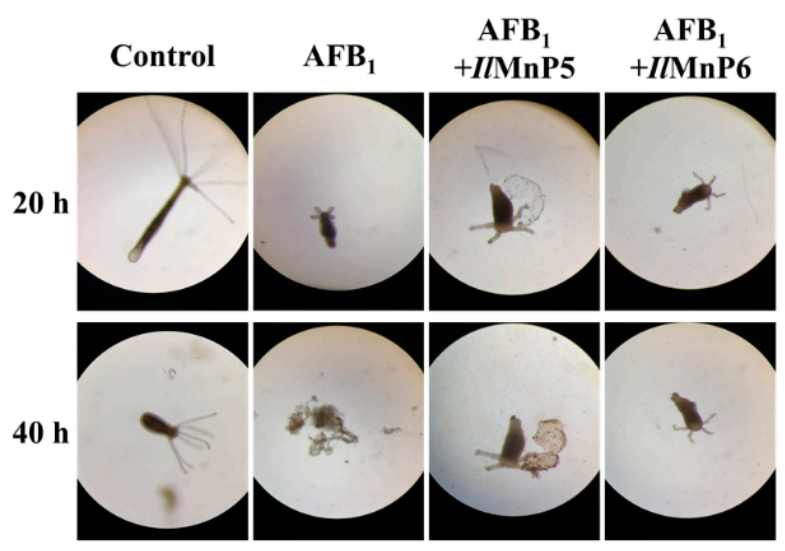

(b)

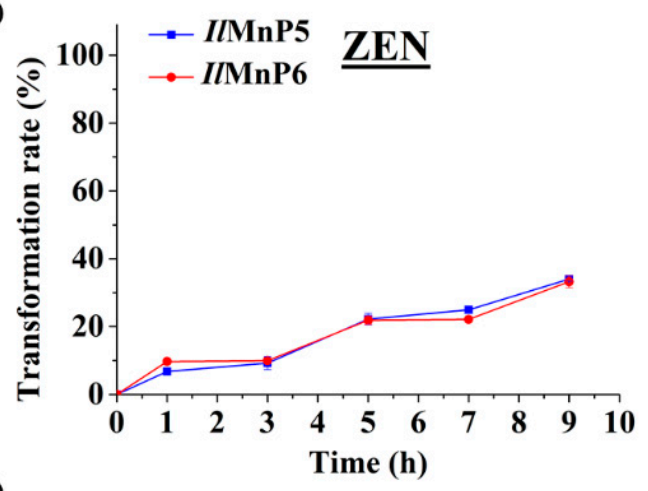

(d)

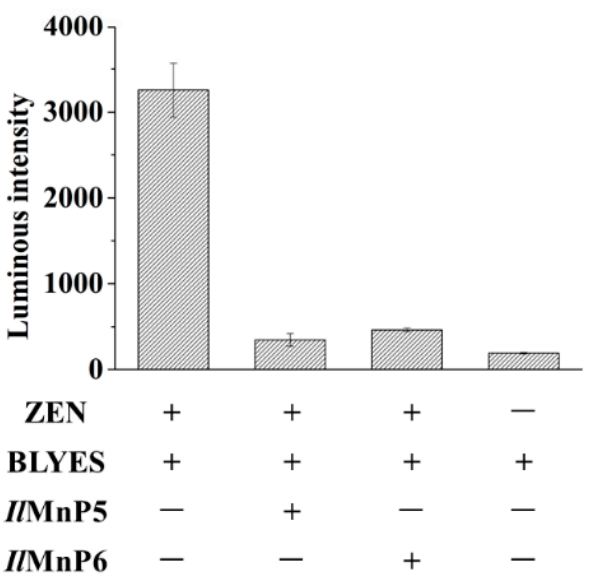

Figure 2. Degradation of $\mathrm{AFB}_{1}$ and ZEN by IlMnP5 and IlMnP6 in a malonate buffer. (a,b) Time-course analysis of $\mathrm{AFB}_{1}$ (a) and ZEN (b) degradation by IlMnP5 and IlMnP6. (c) Treating $\mathrm{AFB}_{1}$ using IlMnP5 and $I l \mathrm{MnP} 6$ alleviated its toxicity on hydra. (d) IlMnP5 and IlMnP6 reduced the estrogenic activity of ZEN to the BLYES yeast.

LC-MS/MS analyses of $\mathrm{AFB}_{1}$ transformation by $I l \mathrm{MnP} 5$ and IlMnP6 (Figure S2a) revealed similar reaction as reported by other researchers [11].

$\mathrm{A}[\mathrm{M}+\mathrm{H}]^{+}$ion was found at $m / z 329.1888$ (Figure S2a). Its molecular weight was 16 Da higher than $\mathrm{AFB}_{1}$, suggesting that 8,9-vinyl bond of $\mathrm{AFB}_{1}$ might be oxidized by $\mathrm{MnP}$ and an oxygen atom was added to the molecule to form $\mathrm{AFB}_{1}-8,9$-epoxide (Figure $3 \mathrm{a}$ ). Note that the product ions $\mathrm{m} / \mathrm{z}$ $313.0744,285.0705,268.9351$ were exactly the same with $\mathrm{AFB}_{1}$ standard, indicative of same mother nucleus structures. For ZEN transformation, $\mathrm{a}[\mathrm{M}+\mathrm{H}]^{+}$ion was found at $m / z 283.2819$ (Figure $\mathrm{S} 2 \mathrm{~b}$ ). This indicated that the removal of the two hydroxyl group might occur in the benzene ring of ZEN (Figure 3b). 
(a)

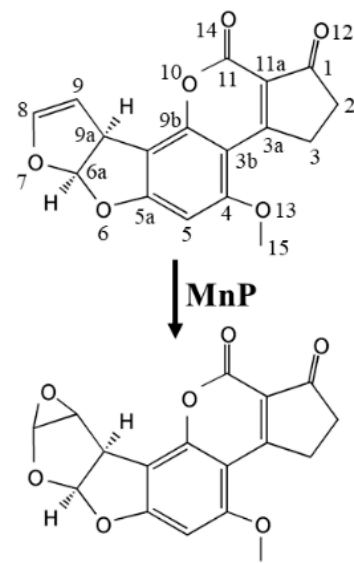

(b)

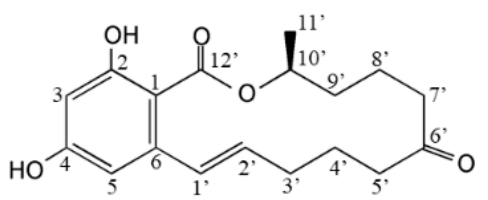

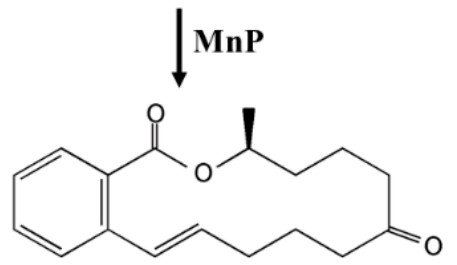

Figure 3. Identified reaction products with proposed structures in $\mathrm{AFB}_{1}(\mathbf{a})$ and $\mathrm{ZEN}(\mathbf{b})$ treated with IlMnP5 and IlMnP6, which were deduced from LC-MS/MS and literature review.

\subsection{Radicals Play an Important Role in Mycotoxin Degradation by IlMnP5 and IlMnP6}

The success of degrading two structurally different mycotoxins by IlMnP5 and IlMnP6 was clearly indicative of substrate promiscuity. In MnP-participated lignin degradation, the nonspecific reaction is underscored by the generation of free radicals, which can attack diverse linkages in the lignin polymer. We next determined if free radicals were also involved in the detoxification of $\mathrm{AFB}_{1}$ and $\mathrm{ZEN}$. Transformation of $\mathrm{AFB}_{1}$ depended heavily on the buffer system because changing malonate to either acetate or lactate almost completely abolished the degrading ability of IlMnP5 and IlMnP6 (Figure 4a). In contrast, both enzymes could transform $\mathrm{ZEN}$ in the presence of malonate, acetate, and lactate (Figure $4 \mathrm{~b}$ ). Only very minor product peaks were observed when $\mathrm{AFB}_{1}$ reacted with MnPs in malonate. Two small peaks appeared in $\mathrm{MnP}$-treated $\mathrm{AFB}_{1}$ samples, but no other new peaks were observed even when the products were extensively scanned from 190 to $400 \mathrm{~nm}$ (data not shown). Similar to the situation in $\mathrm{AFB}_{1}$ degradation, only very small product peaks were observed for the reactions with $\mathrm{ZEN}$ in presence of malonate buffer where radicals seemed to play a vital role. No other new peaks were observed when the products were also scanned from 190 to $400 \mathrm{~nm}$ for ZEN treated with IlMnP5 and IlMnP6 in presence of malonate (data not shown). In acetate buffer where free radicals could not be generated, a large product peak (with retention time: $20.3 \mathrm{~min}$ ) was observed. The $\alpha$-hydroxyl carboxylate lactate could serve as a weaker chelating reagent with $\mathrm{Mn}^{3+}$ [22], thus also leading to free radical generation.

$\mathrm{Mn}^{3+}$, an oxidized product by $\mathrm{MnP}$, chelates with malonate and leads to the release of alkyl, alkylperoxy, and superoxide radicals $[13,23]$. Free radicals can be eliminated by treatment using an enzyme or chemical scavenger. Superoxide dismutase (SOD) is effective in eliminating superoxide radical, while rutin is a strong alkylperoxyl radical scavenger [24]. We found that, in malonate buffer, SOD slightly but significantly, while rutin largely inhibited the degradation of $\mathrm{AFB}_{1}$ and $\mathrm{ZEN}$, by IlMnP5 and IlMnP6 (Figure 4c-f). These data undoubtedly demonstrated that radicals are indeed involved in MnP-catalyzed mycotoxin degradation and therefore are responsible for the nonspecific reactions. In malonate, with part of ZEN being degraded, small product peaks were again observed. Acetate is not able to chelate $\mathrm{Mn}^{3+}$. However, a large product peak (retention time: 20.3 min) was observed for ZEN reacted with MnPs in this buffer (Figure 4b). The significant ZEN transformation in acetate suggests that IlMnP5 and IlMnP6 directly reacted with ZEN, possibly by oxidizing the phenolic hydroxyl groups, which is a typical feature of MnPs [22]. Lactate is an $\alpha$-hydroxyl carboxylate and can also chelate with $\mathrm{Mn}^{3+}$ [22]. However, a significant product peak of $20.3 \mathrm{~min}$ was also observed when ZEN was incubated with MnPs in lactate (Figure 4b). 
(a)

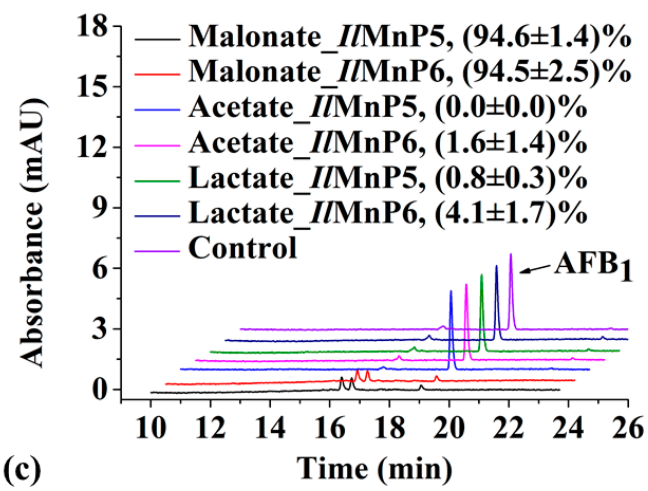

18 — Malonate $I / \mathrm{MnP5},(91.0 \pm 0.26) \%$

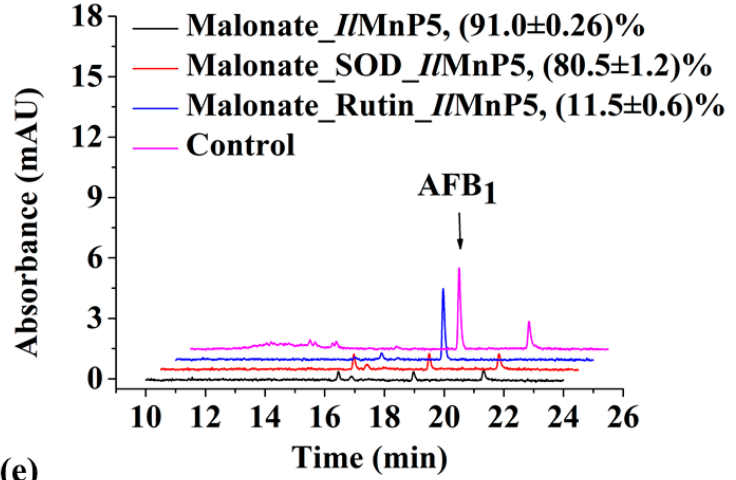

(e)

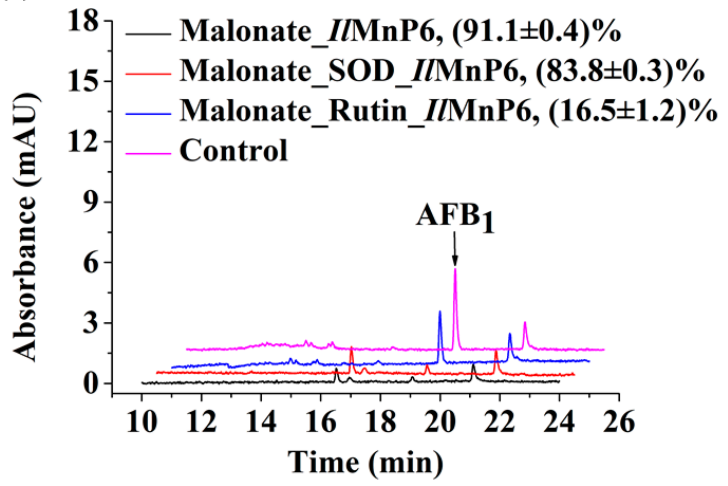

(b)
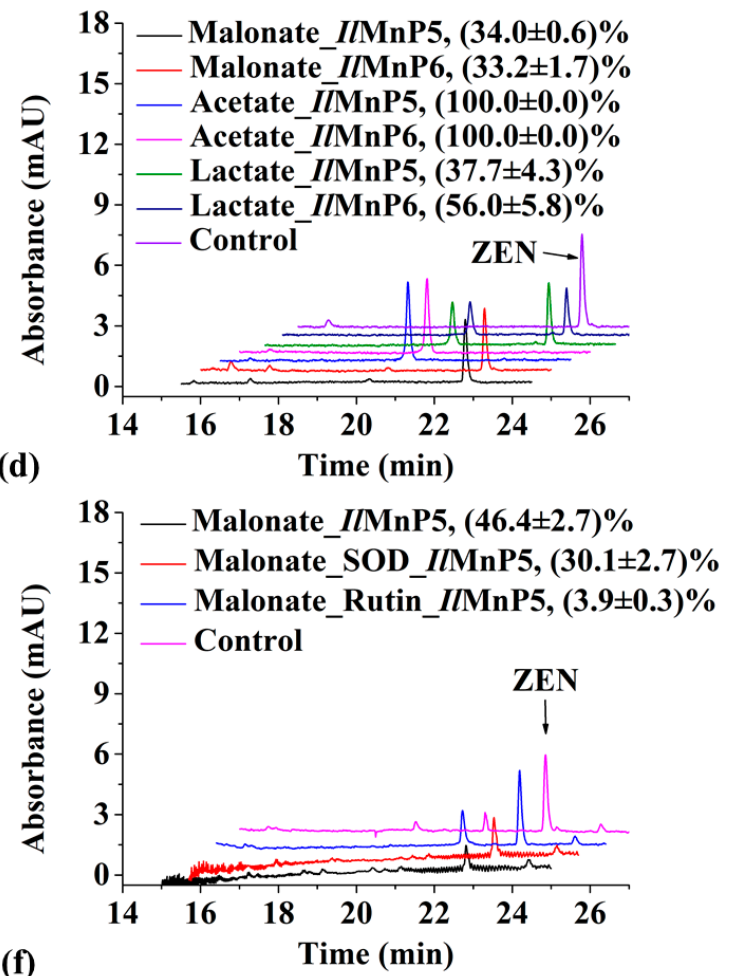

(f)

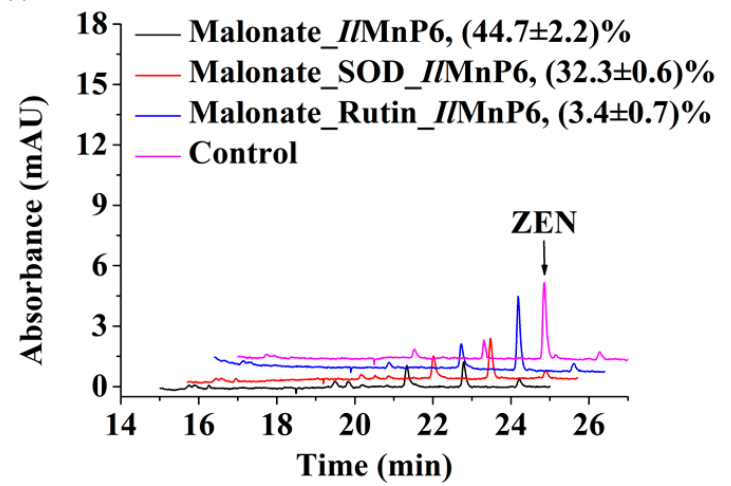

Figure 4. Radicals play an important role in mycotoxin degradation by IlMnP5 and IlMnP6. $(\mathbf{a}, \mathbf{b})$ Degradation of $\mathrm{AFB}_{1}(\mathbf{a})$ and ZEN (b) in malonate, lactate, or acetate buffers. (c,d) Effects of SOD and rutin on the degradation of $\mathrm{AFB}_{1}$ (c) and ZEN (d) by IIMnP5. (e,f) Effects of SOD and rutin on degradation of $\mathrm{AFB}_{1}$ (e) and ZEN (f) by IlMnP6. Note that the height of the traces of ZEN degradation was doubled for ease of observation. The degradation percentage was labeled for each enzyme-treated sample, represented as average \pm standard deviation.

\subsection{Degradation of Multiple Mycotoxins Is a common Feature Shared by Manganese Peroxidases}

We then proceeded to investigate if IlMnP5 and IlMnP6 could also degrade other mycotoxins and, more importantly, if the ability to degrade multiple mycotoxins is a feature shared by other $\mathrm{MnPs}$, as well. For this purpose, the other three main mycotoxins as addressed above, i.e., DON $(10 \mu \mathrm{g} / \mathrm{mL}), \mathrm{FB}_{1}(10 \mu \mathrm{g} / \mathrm{mL})$, and OTA $(50 \mu \mathrm{g} / \mathrm{mL})$, were selected for testing. DON and $\mathrm{FB}_{1}$ do not have a phenolic hydroxyl group. Therefore, although for ZEN degradation, MnP performed best in the acetate buffer, to maximize the substrate promiscuity of MnPs, the malonate buffer (but not the acetate buffer) favoring radical production was used.

Eight MnP genes, including IlMnP5 and IlMnP6 and the other three from I. lacteus (IlMnP1, $I l M n P 2$, and IlMnP4, IlMnP5, and IlMnP6) [12], one from P. chrysosporium (PcMnP1) [11,25], one 
from C. subvermispora (CsMnP) [26], and one from $N$. frowardii ( $N f M n P)$ were either expressed as recombinant proteins or purchased (for $N f \mathrm{MnP}$, from Sigma-Aldrich, catalog \# 41563), were selected for testing (Figure S3). In the 72-h incubation when the reactions commonly reached a plateau (Figure S4), although the eight MnP enzymes displayed only negligible activity on OTA, they were quite effective in degrading $\mathrm{AFB}_{1}, \mathrm{ZEN}, \mathrm{DON}$, and $\mathrm{FB}_{1}$, with the highest rates amounting up to $100 \%$ (Figure 5a). For mycotoxins degradation, the I. lacteus and C. subvermispora MnPs behaved similarly, with transformation rates varying from $90.9-100 \%$ (for $\mathrm{AFB}_{1}$ ), $90.2-94.3 \%$ for $\mathrm{ZEN}, 34.1-43.6 \%$ for $\mathrm{FB}_{1}$, respectively. For DON, IlMnP1 had a relatively lower transformation rate of $76.8 \%$, compared to $92.9-96.3 \%$ for $I l \mathrm{MnP} 2$, IlMnP4, IlMnP5, IlMnP6, and CsMnP. PcMnP1 and NfMnP had similar transformation rates for $\mathrm{DON}$ and $\mathrm{FB}_{1}(42.9-43.5 \%$ and $22.2-30.2 \%$, respectively). PcMnP1 was less effective than $C s \mathrm{MnP}$ in transforming $\mathrm{AFB}_{1}$ and $\mathrm{ZEN}$ (46.1\% and $29.1 \%$ for $P c \mathrm{MnP} 1$, and $78.4 \%$ and $42.2 \%$ for $C s \mathrm{MnP}$, respectively). However, both enzymes were outperformed by the I. lacteus and N. frowardii MnPs. Similar to $\mathrm{AFB}_{1}$ and $\mathrm{ZEN}$ reacted with MnPs, no large product peak was observed for DON incubated with MnPs in HPLC analysis. For DON and $\mathrm{FB}_{1}$, the reaction mixtures were subjected to UHPLC/MS-MS analysis but we were not able to identify a structurally determined product in the search, possibly because of the complexity of the reaction.

(a)

\begin{tabular}{ccccc}
\hline & $\begin{array}{c}\text { AFB1 } 1 \\
(\%)\end{array}$ & $\begin{array}{c}\text { ZEN } \\
(\%)\end{array}$ & $\begin{array}{c}\text { DON } \\
(\%)\end{array}$ & $\begin{array}{c}\text { FB1 } \\
(\%)\end{array}$ \\
\hline IlMnP1 & 100 & 93 & 76 & 43 \\
IlMnP2 & 100 & 93 & 94 & 34 \\
IlMnP4 & 100 & 91 & 96 & 38 \\
IlMnP5 & 100 & 92 & 96 & 43 \\
IlMnP6 & 100 & 94 & 94 & 34 \\
PclMnP1 & 46 & 29 & 43 & 30 \\
CsMnP & 90 & 90 & 92 & 25 \\
NfMnP & 78 & 42 & 42 & 22 \\
\hline
\end{tabular}

(b)

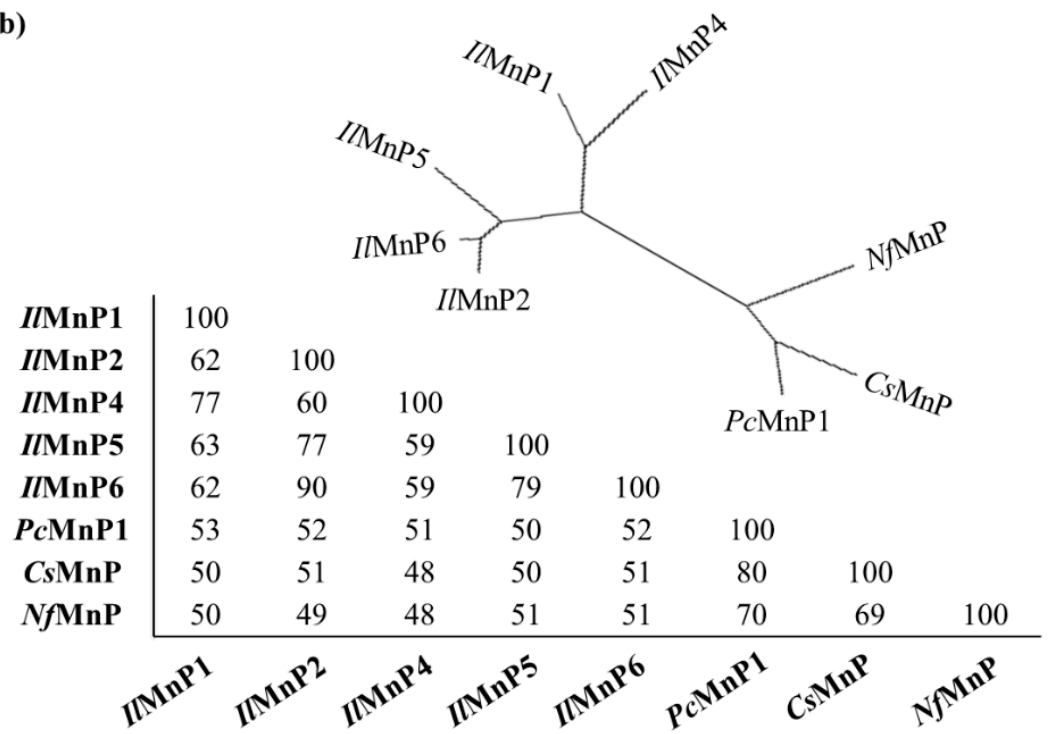

Figure 5. Degradation of multiple mycotoxins is a feature shared by eight MnPs. (a) Degradation percentages for five main mycotoxins by eight MnPs from I. lacteu, P. chrysosporium, C. subvermispora, and $N$. frowardii. The mycotoxins were incubated for $72 \mathrm{~h}$ with one of the enzymes $(0.5 \mathrm{U} / \mathrm{mL}$ each $)$ at $30{ }^{\circ} \mathrm{C}$. (b) Phylogenic tree and the reciprocal amino acid sequence identity of the eight MnPs. 
It is also noted that these MnPs are much diversified as shown in the phylogenic tree and their reciprocal amino acid sequence homology is as low as $48.0 \%$ (Figure $5 \mathrm{~b}$ ). This indicates that mycotoxin detoxification is a common feature shared by these MnPs and possibly other MnPs, as well.

\subsection{Degradation of Mycotoxins Was Related to RB5 Decolorization}

MnPs have been used in decolorization of synthetic dyes [27]. If the rate of dye decolorization by MnPs is positively related to that of mycotoxin degradation, dye decolorization could then be used as a safe indicator, speeding up the discovery of novel MnPs with mycotoxin-degrading ability or evolving MnPs with higher degrading ability. The structure of RB5 is given in Figure 1, which shares similar features (such as phenolic groups) with some mycotoxins but is much different by having the azo and sodium sulfonate groups. Using IlMnP5 and IlMnP6 as model MnPs, it was found that SOD slightly but significantly, while rutin largely inhibited the decolorization of a synthetic azo dye RB5, similar to that observed for $\mathrm{AFB}_{1}$ and ZEN detoxification (Figure S5). This demonstrated that radicals are also involved in RB5 decolorization. Thus, free radicals attacking could be overlappingly used by the MnPs in mycotoxin detoxification and RB5 decolorization. This suggests that RB5 decolorization may serve as an indicator of radical performance, and further, mycotoxin degradation. Indeed, the decolorization rates of RB5 by the eight MnPs were positively related to the degradation rates for the four major mycotoxins, with $R^{2}$ equaling $0.710-0.945$ (Figure 6a-d). Therefore, the ability to decolorize a synthetic dye (specifically RB5 as a prototype) could be used to estimate the potential of a MnP to degrade mycotoxins.

(a)

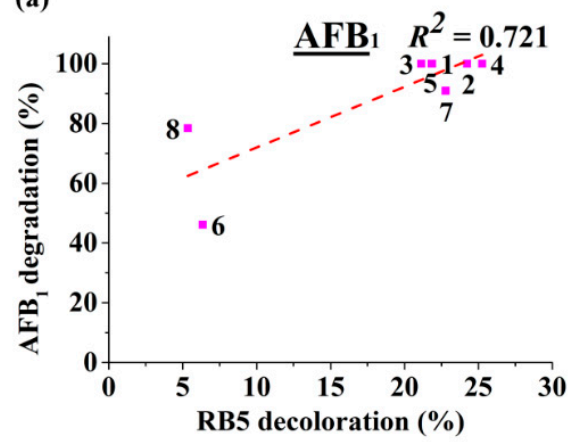

(c)

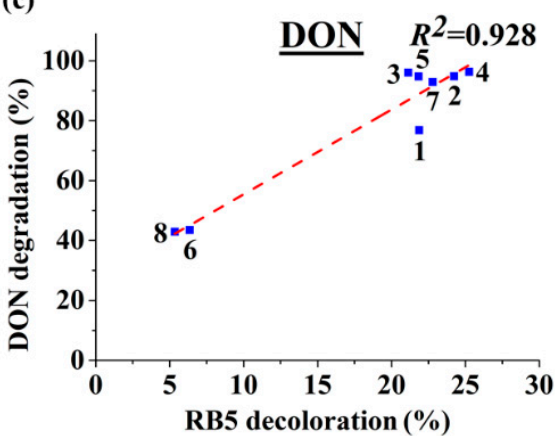

(b)

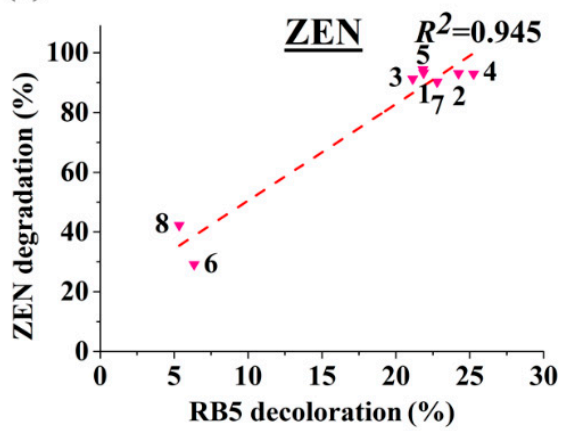

(d)

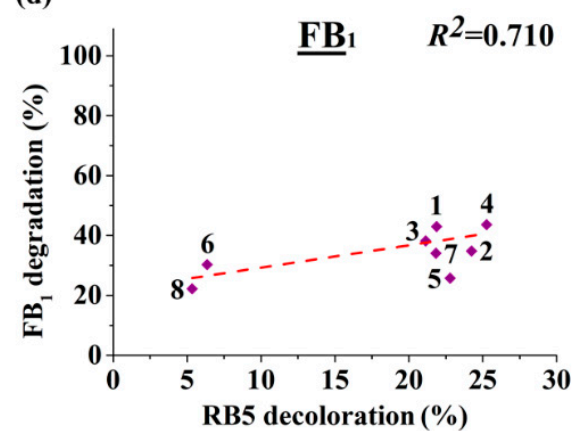

Figure 6. Degradation of four major mycotoxins $\left(\mathrm{AFB}_{1}, \mathrm{ZEN}, \mathrm{DON}\right.$, and $\left.\mathrm{FB}_{1}, 72 \mathrm{~h}\right)$ was positively related to RB5 decolorization (9 h). The enzymes (IlMnP1, IlMnP2, IlMnP4, IlMnP5, IlMnP6, PcMnP1, CsMnP, and $N f \mathrm{MnP}$ ) are labeled with the numbers 1-8, respectively. (a) Degradation percentages of $\mathrm{AFB}_{1}$ was positively related to RB5 decolorizations by enzymes $\left(R^{2}=0.721\right)$. (b) Degradation percentages of ZEN was positively related to RB5 decolorizations by enzymes $\left(R^{2}=0.945\right)$. (c) Degradation percentages of DON was positively related to RB5 decolorizations by enzymes $\left(R^{2}=0.928\right)$. (d) Degradation percentages of $\mathrm{FB}_{1}$ was positively related to RB5 decolorizations by enzymes $\left(R^{2}=0.720\right)$. 


\section{Discussion}

Currently, there are approximately 500 known mycotoxins [28]. The structural diversity, in combination with co-contamination of multiple mycotoxins in food or feed, dwarfs the endeavors to use one or a limited number of enzymes for detoxification. However, in this study, we demonstrated that, MnPs can degrade at least four major mycotoxins instead of only one (i.e., $\mathrm{AFB}_{1}$, as have been reported previously) [11]. Although OTA has a phenolic hydroxyl group which is commonly the well-accepted substrate of MnPs, the tested MnPs were ineffective in its degradation. The underlying reason remains unknown.

For $\mathrm{AFB}_{1}$, degradation was mainly through the free radicals, which were generated by interaction of oxidized $\mathrm{Mn}^{3+}$ with the dicarboxylic acid malonate. $\mathrm{AFB}_{1}-8,9$-epoxide is labile in aqueous solution and its autonomous hydrolysis product can be monitored at $365 \mathrm{~nm}$ [29], the same wavelength used to detect disappearance of $\mathrm{AFB}_{1}$. Therefore, these together suggested that most chromophore groups (such as the benzene ring) in $\mathrm{AFB}_{1}$ had been eliminated in $\mathrm{MnP}$ treatment and the observed $\mathrm{AFB}_{1}-8$,9-epoxide (in UHPLC/MS-MS analysis) and new product peaks in HPLC analysis are likely minor parts of the products. The fact that $\mathrm{AFB}_{1}-8,9$-epoxide only constituted a small fraction of the products in our experiment is of significance. This is because $\mathrm{AFB}_{1}-8,9$-epoxide is not a desirable product and it irreversibly attaches to guanine residues to generate highly mutagenic DNA adducts [30].

The nature of other and major complex degradation products remains to be unveiled. This finding appears to be applicable to MnP-catalyzed ZEN degradation, as well. However, since the $20.3 \mathrm{~min}$ product peak was present, it could be imagined that direct reaction of MnP with ZEN could also happen. With these observed, there appeared to be some competition between the two pathways leading to ZEN degradation, i.e., direct reaction of a MnP with ZEN and indirect reaction via free radicals, since the degradation rates of ZEN by IlMnP5 and IlMnP6 in lactate buffer were higher than those in malonate buffer but lower than those in acetate buffer.

The huge number of mycotoxins prevents us from testing the efficacy of the eight MnPs in their degradation one by one. However, given the wide reactivity of free radicals generated by MnPs, amended by direct interaction of MnPs with substrates containing the phenolic hydroxy, phenylamine, and azino linkages [8], it is very likely that other mycotoxins can also be degraded. More importantly, it appears that the ability to degrade multiple mycotoxins is not restricted to one specific MnP but tends to be a common feature shared by this kind of enzymes. In this study, although the toxicity of degradation products of $\mathrm{DON}$ and $\mathrm{FB}_{1}$ was not evaluated, we observed much reduced toxicity $\left(\mathrm{AFB}_{1}\right)$ or estrogenicity (ZEN) for $\mathrm{AFB}_{1}$ and ZEN degraded by IlMnP5 and IlMnP6 using the hydra and BLYES yeast assays, suggesting the application potential of these enzymes in mycotoxin detoxification. Nevertheless, it has to be admitted that these preliminary assays used much simplified model systems and cannot completely reflect the true scenarios where mycotoxins exert their roles in human and animals. For example, in addition to its toxicity, $\mathrm{AFB}_{1}$ is well-known for its carcinogenicity and causes cancer in the liver, kidney, and colon [31]. Therefore, a detailed study of the nature of the complex degradation products for all the tested mycotoxins, as well as their toxicity to cultured cells and animal models have to be systematically investigated. Two or more mycotoxins are commonly observed to co-exist but the types of mycotoxins vary among different foods and feeds [32]. If the MnP-catalyzed degradation products of certain specific combinations of mycotoxins are, in future, proved to be of less or even no toxicity to animals and human, $\mathrm{MnP}$ can truly serve as a candidate enzyme for detoxification because of its capability to degrade multiple mycotoxins.

We also demonstrated that RB5 decolorization may be used as a starting point to dictate discovery of new MnPs, through which the risk of handling mycotoxin will be greatly reduced. As $\mathrm{MnP}$ is classified in a large although expanding CAZy (Carbohydrate Active Enzymes) family (http://www.cazy.org/AA2.html) [33], it is therefore expected that the current finding of broad-spectrum mycotoxin-degrading enzymes will be used as a guiding framework to facilitate future discovery of robust mycotoxin-degrading enzymes with desirable properties. Additionally, this method can also be used for high-throughput screening of $\mathrm{MnP}$ variants with improved properties such as higher velocity 
of transformation, which may be generated from (semi)rational design or directed evolution. This is important since the time of incubation with the four mycotoxins is as long as $72 \mathrm{~h}$ in this study (Figure 5). From a practical perspective, a MnP with higher efficiency as well as higher velocity of transformation would be much more preferred.

One drawback of using MnPs for mycotoxins degradation (and potentially, detoxification) is the difficulty in obtaining large quantities of such enzymes. White-rot fungi, such as P. chrysosporium, C. subvermispora, and I. lacteus, are a natural microbial source rich in $\mathrm{MnP}$ genes. However, the white rots are divided into simultaneous and selective lignocellulose degraders, which differ in their way of regulating expression of the lignin-degrading enzymes (including MnPs) [14]. For instance, while $P$. chrysosporium gradually increases expression of MnPs (and other lignin-degrading enzymes) during culture on lignocellulose [15], the selective lignocellulose degraders C. subvermispora and I. lacteus only express MnPs at the early stage of culturing [12,34]. Therefore, care has to be taken in monitoring the expression of MnPs if such enzymes are to be produced from these microorganisms. MnPs can also be made in Pichia pastoris [35] or filamentous fungi [36]; however, they are notoriously hard to express recombinantly. In addition, the prosthetic group hemin has to be supplemented to the culture as an expensive additive for the formation of functional proteins. Thus future efforts can be placed in genetic engineering of the commonly used platform industrial microbes to facilitate large scale, heterologous production of MnPs.

Although MnPs were the only enzymes investigated in this study, because of the important role of free radicals involved, it is proposed that other oxidoreductases may also have the ability to degrade mycotoxins. Specifically, another lignin-degrading enzyme, laccase [37] (and probably other peroxidases as well), may also be used in mycotoxin degradation once a reaction condition is settled up favoring generation of mycotoxin-attacking radicals. Mediators (i.e., small molecules reacting with a laccase) play key roles in dictating the scope of a laccase and amplifying its catalyzing efficiency [38]. Both artificial and natural mediators can be screened if laccase is to be employed in mycotoxin degradation. Indeed, the Ery4 laccase from Pleurotus eryngii has been used to degrade $\mathrm{AFB}_{1}$, $\mathrm{ZEN}, \mathrm{FB}_{1}$, and OTA in presence of a few structurally defined chemicals, such as acetosyringone and syringaldehyde, albeit with lower efficiency [31]. Interesting, the laccase/mediator system can degrade OTA but cannot act on DON, while the MnP/malonate system can degrade DON but not OTA. All in all, the versatility of manganese peroxidase makes it a candidate enzyme to simultaneously degrade multiple and much differing mycotoxins in food and feed, although a systematic investigation of the toxicity of the degradation products to animals and human has to be implemented ahead of that.

\section{Conclusions}

In summary, eight MnPs were found to be able to degrade four major mycotoxins, $\mathrm{AFB}_{1}, \mathrm{ZEN}$, $\mathrm{DON}$, and $\mathrm{FB}_{1}$ in the presence of a dicarboxylic acid malonate, in which free radicals play important roles. The ability to degrade multiple mycotoxins is not restricted to one MnP but tends to be shared by MnPs with much diversified sequences. We also demonstrated that RB5 decolorization may be used as a starting point to dictate discovery of new MnPs, through which the risk of handling mycotoxin will be greatly reduced. Our research suggests the possibility of using $\mathrm{MnP}$ as a candidate enzyme to degrade multiple mycotoxins simultaneously in food or feed if careful surveillance of the residual toxicity of degradation products is properly carried out.

\section{Materials and Methods}

\subsection{Chemicals and Other Materials}

$\mathrm{AFB}_{1}, \mathrm{ZEN}, \mathrm{DON}$, and the commercial Nematoloma frowardii manganese peroxidase (NfMnP) were purchased from Sigma-Aldrich (St. Louis, MO, USA). $\mathrm{FB}_{1}$ and OTA were purchased from Pribolab (Beijing, China). Hemin was purchased from TCI (Tokyo, Japan). DNA polymerase, T4 ligase, and chromatographic grade reagents (acetonitrile, methanol, methanoic acid, acetic acid, 
and trifluoroacetic acid) were purchased from Thermo Fisher Scientific (Waltham, MA, USA). DNase I and TransScript One-Step gDNA Removal and cDNA Synthesis Supermix with oligo(dT) were purchased from TransGen (Beijing, China). Isopropyl- $\beta$-D-thiogalactoside (IPTG), SOD, DTT, and Rutin were purchased from Solarbio (Beijing, China). TRIZOL was from Invitrogen (Carlsbad, CA, USA). Lysozyme was purchased from Amresco (Solon, OH, USA). Ni-NTA agarose was purchased from QIAGEN (Duesseldorf, Germany). All other chemicals were of analytical grade or chromatographically pure, and were commercially available.

\subsection{Plasmids, Bacterial Strains, and Cultural Conditions}

The plasmids used in this study for expression of recombinant MnPs were pET-28a-IlMnP1, pET28a-IlMnP2, pET28a-IlMnP4, pET28a-IlMnP5, pET28a-IlMnP6, pET28a-PcMnP1, and pCold $\mathrm{I}-\mathrm{CsMnP}$ (Figure S6). Irpex lacteus CD2 was isolated from Shennong Nature Reserve (Hubei province, China) and maintained at $4{ }^{\circ} \mathrm{C}$ on potato-dextrose agar (PDA) plate. The Escherichia coli Trans1-T1 was used for gene cloning and plasmid propagation. The E. coli BL21 (DE3) strain was used for the expression of enzymes. These $E$. coli strains were cultivated at $37^{\circ} \mathrm{C}$ with constant shaking at $220 \mathrm{rpm}$ in Luria-Bertani (LB) broth medium: tryptone $(10 \mathrm{~g})$, yeast extract $(5 \mathrm{~g})$, and $\mathrm{NaCl}(10 \mathrm{~g})$ in water $(1 \mathrm{~L}$, $\mathrm{pH} 7.0)$ containing appropriate antibiotics.

\subsection{Construction of Recombinant Plasmids}

The primers used in this study are listed in Table S1. I. lacteus CD2 was grown for $5 \mathrm{~d}$ in the basal liquid medium. Total RNA was extracted using the TRIZOL reagent according to the manufacturer's instructions and reverse transcribed to the first strand cDNA using the TransScript One-Step gDNA Removal and cDNA Synthesis Supermix with oligo (dT). The Phanerochaete chrysosporium PcMnP1 (GenBank: J04980.1) [25] and Ceriporiopsis subvermispora CsMnP (GenBank: MG190336.1) [26] genes devoid of the sequences encoding the signal peptide were synthesized by BGI (Beijing, China). The three-dimensional structures of two homologs of $P c \mathrm{MnP1}$ and $C s \mathrm{MnP}$ have been solved, which can be found at the protein structure database (http://www.rcsb.org/) with the entry numbers of 1MNP [39] (or 1YYD [40]) and $4 \mathrm{CZN}$ [41], respectively. $P c \mathrm{MnP1}$ has $79 \%$ amino acid sequence identity with $1 \mathrm{MNP}$ (or 1YYD) while $C s \mathrm{MnP}$ has $84 \%$ identity with $4 \mathrm{CZN}$. The I. lacteus, P. chrysosporium, and C. subvermispora $\mathrm{MnP}$ genes were amplified with gene specific primers using the following conditions: $95^{\circ} \mathrm{C}$ for $2 \mathrm{~min}$; then 30 cycles of $95{ }^{\circ} \mathrm{C}$ for $30 \mathrm{~s}, 54{ }^{\circ} \mathrm{C}$ for $30 \mathrm{~s}$, and $72{ }^{\circ} \mathrm{C}$ for $1 \mathrm{~min}$. The amplified genes of $I l M n P$ enzymes and PcMnP1 were restriction digested with EcoRI/NotI, gel purified, and ligated into the pET-28a (+) plasmid pre-digested with the same enzymes to obtain pET-28a-IlMnP1, pET28a-IlMnP2, pET28a-IlMnP4, pET28a-IlMnP5, pET28a-IlMnP6, and pET28a-PcMnP1 (Figure S6). The PCR product of $\mathrm{CsMnP}$ was digested with $\mathrm{NdeI} / \mathrm{BamHI}$, gel purified, and ligated into the pre-digested pCold I (digested

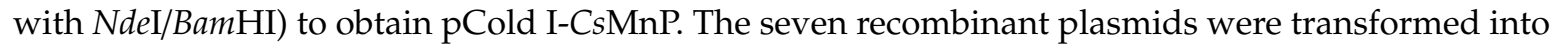
E. coli BL21(DE3) competent cells for gene expression.

\subsection{Expression of Manganese Peroxidases}

The E. coli BL21(DE3) strains harboring pET-28a-IlMnP1, pET-28a-IlMnP2, pET-28a-IlMnP4, pET-28a-IlMnP5, pET-28a-IlMnP6, or pET-28a-PcMnP1 were cultured in LB medium supplemented with $50 \mu \mathrm{g} / \mathrm{mL}$ of kanamycin at $37^{\circ} \mathrm{C}$ overnight with shaking at $220 \mathrm{rpm}$. These pre-cultures were individually inoculated into $200 \mathrm{~mL} \mathrm{LB}$ medium. The culture was continued at $37^{\circ} \mathrm{C}$ for approximately $2 \mathrm{~h}$. When the optical density at $600 \mathrm{~nm}\left(\mathrm{OD}_{600}\right)$ reached $0.6-0.8$, IPTG was added to a final concentration of $1 \mathrm{mM}$ for induction of MnPs expression [13]. For the E. coli BL21(DE3) strain containing pCold $\mathrm{I}-\mathrm{Cs} \mathrm{MnP}$, when $\mathrm{OD}_{600}$ reached 0.5 , the bacterium was rapidly chilled to $10{ }^{\circ} \mathrm{C}$ by soaking the culture flask in a water-ice bath, followed by shaking at $220 \mathrm{rpm}$ at $10{ }^{\circ} \mathrm{C}$ for $30 \mathrm{~min}$. IPTG was added to a final concentration of $0.2 \mathrm{mM}$ and the cells were grown at $10^{\circ} \mathrm{C}$ with shaking at $220 \mathrm{rpm}$ for $24 \mathrm{~h}$. Six hour after IPTG was added, $1 \mathrm{M} \mathrm{CaCl}_{2}$ and $10 \mathrm{~g} / \mathrm{L}$ hemin were supplied continuously for another $9 \mathrm{~h}$ at 
rates of $22 \mu \mathrm{L} / \mathrm{h}$ and $220 \mu \mathrm{L} / \mathrm{h}$ to the $200 \mathrm{~mL} \mathrm{LB}$ culture medium, respectively. After induction, the cells were harvested by centrifugation at $12,000 \mathrm{~g}$ for $2 \mathrm{~min}$ [26].

\subsection{Refolding and Purification of the Recombinant MnPs}

For E. coli expressing recombinant MnPs from I. lacteus and P. chrysosporium MnPs, the harvested cell pellets were re-suspended in $50 \mathrm{mM}$ Tris- $\mathrm{HCl}, 10 \mathrm{mM}$ EDTA, and $5 \mathrm{mM}$ DTT (pH 8.0). Lysozyme was added to a final concentration of $2 \mathrm{mg} / \mathrm{mL}$ and the cells were incubated on ice for $1 \mathrm{~h}$. Then, $20 \mu \mathrm{L}$ of DNase I was added and the incubation was continued on ice for $30 \mathrm{~min}$. Subsequently, the cells were centrifuged at $12,000 \mathrm{~g}$ for $30 \mathrm{~min}$ at $4{ }^{\circ} \mathrm{C}$. The cell debris was washed twice with $20 \mathrm{mM}$ Tris- $\mathrm{HCl}, 1 \mathrm{mM}$ EDTA, and $5 \mathrm{mM}$ DTT (pH 8.0), followed by incubation in $50 \mathrm{mM}$ Tris-HCl, $8 \mathrm{M}$ urea, $1 \mathrm{mM}$ EDTA, and $1 \mathrm{mM}$ DTT ( $\mathrm{pH}$ 8.0) on ice for $1 \mathrm{~h}$. To optimize the parameters for recovery of active enzyme from the inclusion bodies, the refolding was carried out in different conditions. The parameters including concentrations of urea, GSSG, and hemin and $\mathrm{pH}$ were investigated, while the concentrations of enzyme, EDTA, and DTT were kept constant during the refolding. The efficiency of refolding was indicated by the MnP activity. Refolding of the MnPs were conducted under the optimized conditions ( $\mathrm{pH}$ 9.5, $50 \mathrm{mM}$ Tris-HCl buffer, 0.6 M urea, $0.5 \mathrm{mM}$ GSSG, $0.1 \mathrm{mM}$ DTT, $10 \mu \mathrm{M}$ hemin, $5 \mathrm{mM} \mathrm{CaCl}_{2}$, $0.1 \mathrm{mg} / \mathrm{mL}$ protein for IlMnP1; pH $9.550 \mathrm{mM}$ Tris-HCl buffer, $0.5 \mathrm{M}$ urea, $0.7 \mathrm{mM} \mathrm{GSSG}, 0.1 \mathrm{mM}$ DTT, $10 \mu \mathrm{M}$ hemin, $5 \mathrm{mM} \mathrm{CaCl}, 0.1 \mathrm{mg} / \mathrm{mL}$ protein for IlMnP2, IlMnP5 and IlMnP6; pH $9.550 \mathrm{mM} \mathrm{Tris-HCl}$ buffer, $0.5 \mathrm{M}$ urea, $0.7 \mathrm{mM}$ GSSG, $0.1 \mathrm{mM}$ DTT, $10 \mu \mathrm{M}$ hemin, $5 \mathrm{mM} \mathrm{CaCl}, 0.1 \mathrm{mg} / \mathrm{mL}$ protein for IlMnP4; pH 9.550 mM Tris-HCl buffer, 1 M urea, 0.4 mM GSSG, 0.1 mM DTT, $10 \mu \mathrm{M}$ hemin, 5 mM $\mathrm{CaCl}_{2}, 0.1 \mathrm{mg} / \mathrm{mL}$ protein for $\left.P c \mathrm{MnP} 1\right)$ for $10 \mathrm{~h}$ at $15^{\circ} \mathrm{C}$. After refolding, the crude enzymes were centrifuged at $12,000 \mathrm{~g}$ for $10 \mathrm{~min}$ at $4{ }^{\circ} \mathrm{C}$ and the insoluble fractions were discarded. The supernatants containing the refolded $\mathrm{MnP}$ were concentrated through a $10 \mathrm{kDa}$ cut-of centrifuge filter, followed by dialysis against buffers of different $\mathrm{pHs}\left(\mathrm{pH}\right.$ 6.0, $20 \mathrm{mM} \mathrm{Na}_{2} \mathrm{HPO}_{4}$-citric acid buffer for IlMnP1; $\mathrm{pH} 5.0$ 20 mM HAc-NaAc buffer for IlMnP2, IlMnP5, IlMnP6; pH 6.520 mM Na $2 \mathrm{HPO}_{4}$-citric acid buffer for IlMnP4 and PcMnP1). The crude enzymes were further purified by a HiTrap Q HP anion exchange column (GE Health, Fairfeld, CT) pre-equilibrated with the same buffer. The proteins were eluted with a linear gradient of $0-1.0 \mathrm{M} \mathrm{NaCl}$, and fractions containing pure and active enzymes were pooled [13].

The E. coli cell pellet expressing recombinant CsMnP was harvested from $100 \mathrm{~mL}$ of culture medium, re-suspended in $10 \mathrm{~mL}$ of $50 \mathrm{mM}$ Tris- $\mathrm{HCl}$ buffer ( $\mathrm{pH} \mathrm{8.0)}$ containing $1 \mathrm{mM} \mathrm{CaCl}$, and homogenized by sonication. After centrifugation at $12,000 \mathrm{~g}$ for $30 \mathrm{~min}$, the cell debris was discarded and the supernatant was collected, which was passed through a $\mathrm{Ni}$ affinity column resin. The resin was washed with $50 \mathrm{mM} \mathrm{Na}_{2} \mathrm{HPO}_{4}-\mathrm{NaH}_{2} \mathrm{PO}_{4}$ buffer (pH 7.5) containing $500 \mathrm{mM} \mathrm{NaCl}, 1 \mathrm{mM} \mathrm{CaCl}_{2}$, and $20 \mathrm{mM}$ imidazole to remove the nonspecifically bound proteins. The bound MnPs were eluted with $50 \mathrm{mM}$ Tris-HCl (pH 7.5) containing $500 \mathrm{mM} \mathrm{NaCl}, 1 \mathrm{mM} \mathrm{CaCl}$, and 40/60/80/100/200/500 mM imidazole, respectively. The eluents were analyzed for purity by SDS-PAGE. The purified MnPs were stored in $50 \mathrm{mM}$ Tris- $\mathrm{HCl}(\mathrm{pH} 7.5)$ at $4{ }^{\circ} \mathrm{C}$ containing $1 \mathrm{mM} \mathrm{CaCl}_{2}$ until used [26]. The purified recombinant manganese peroxidases were analyzed on SDS-PAGE (Figure S3).

\subsection{Measurement of MnP Activity}

The MnP activity was measured by monitoring the oxidation of 2,2' -Azino-bis(3-ethylbenzothiazoline6-sulphonic acid (ABTS, $\varepsilon 420=36,000 \mathrm{M}^{-1} \cdot \mathrm{cm}^{-1}$ ) at $420 \mathrm{~nm}$, in a buffer containing $50 \mathrm{mM}$ malonate, $1 \mathrm{mM}$ ABTS, $1 \mathrm{mM} \mathrm{MnSO}_{4}$, and $0.1 \mathrm{mM} \mathrm{H}_{2} \mathrm{O}_{2}\left(\mathrm{pH} 5.0\right.$ and $25^{\circ} \mathrm{C}$ ) [13]. One unit (1 U) of MnP activity was defined as the amount of enzyme that produced $1 \mu \mathrm{mol}$ of product per minute under the standard assay condition.

\subsection{Mycotoxin Degradation}

The activities of the enzymes were first determined using ABTS as the substrate. Each of the calibrated enzymes $\left(0.5 \mathrm{U} / \mathrm{mL}\right.$ each) was then incubated with mycotoxins $\left(\mathrm{AFB}_{1}\right.$ and $\mathrm{ZEN} 5 \mu \mathrm{g} / \mathrm{mL}$; $\mathrm{DON}$, and $\mathrm{FB}_{1}, 10 \mu \mathrm{g} / \mathrm{mL}$; OTA, $50 \mu \mathrm{g} / \mathrm{mL}$ ) in $70 \mathrm{mM}$ malonate buffer supplemented with $1 \mathrm{mM} \mathrm{MnSO}_{4}$ 
and $0.1 \mathrm{mM} \mathrm{H}_{2} \mathrm{O}_{2}$. The reaction was carried out at $30^{\circ} \mathrm{C}$. Periodically, samples were taken out and three volumes of methanol were added to terminate the reaction. Each reaction was repeated three times.

\subsection{RB5 Decolorization}

The reactions were carried out at $30^{\circ} \mathrm{C}$ in a total volume of $200 \mu \mathrm{L}$ containing $50 \mathrm{mM}$ malonate buffer (pH 5.0), $0.1 \mathrm{mM} \mathrm{H}_{2} \mathrm{O}_{2}, 1 \mathrm{mM} \mathrm{Mn}^{2+}, 0.25 \mathrm{U} / \mathrm{mL}$ each of the MnPs, and $50 \mu \mathrm{g} / \mathrm{mL}$ of dye. During the incubation, the color change was detected by measuring the $\mathrm{OD}_{556}$ (RB5). The rate of decolorization was calculated using the following formula: decolorization $(\%)=[(\mathrm{Ai}-\mathrm{At}) / \mathrm{Ai}] \times 100$, where Ai and At are the absorbance at the initial and a given time [13].

\subsection{BLYES Assay}

The Saccharomyces cerevisiae BLYES strain was inoculated into $30 \mathrm{~mL} \mathrm{YMM}\left(\left(\mathrm{NH}_{4}\right)_{2} \mathrm{SO}_{4}\right) 1.7 \mathrm{~g} / \mathrm{L}$, $\mathrm{CuSO}_{4} 12$ mg/L, FeSO 684 g/L, $\mathrm{KH}_{2} \mathrm{PO}_{4} 11.6 \mathrm{~g} / \mathrm{L}, \mathrm{KOH} 3.6 \mathrm{~g} / \mathrm{L}, \mathrm{MgSO}_{4} 171 \mu \mathrm{g} / \mathrm{L}$, D-(+)-glucose $20 \mathrm{~g} / \mathrm{L}$, biotin $20 \mu \mathrm{g} / \mathrm{L}$, pantothenic acid $400 \mu \mathrm{g} / \mathrm{L}$, inositol $1 \mathrm{mg} / \mathrm{L}$, pyridoxine $400 \mu \mathrm{g} / \mathrm{L}$, thiamine $400 \mu \mathrm{g} / \mathrm{L}$, adenine $42.7 \mathrm{mg} / \mathrm{L}$, arginine $\mathrm{HCl} 17.1 \mathrm{mg} / \mathrm{L}$, aspartic acid $100 \mathrm{mg} / \mathrm{L}$, glutamic acid $85.5 \mathrm{mg} / \mathrm{L}$, histidine $42.73 \mathrm{mg} / \mathrm{L}$, isoleucine $25.64 \mathrm{mg} / \mathrm{L}$, lysine $\mathrm{HCl} 25.64 \mathrm{mg} / \mathrm{L}$, methionine $17.1 \mathrm{mg} / \mathrm{L}$, phenylalanine $21.4 \mathrm{mg} / \mathrm{L}$, serine $320.4 \mathrm{mg} / \mathrm{L}$, threonine $192 \mathrm{mg} / \mathrm{L}$, tyrosine $25.7 \mathrm{mg} / \mathrm{L}$ ) in a baked $250 \mathrm{~mL}$ glass flask. The cells were cultured at $28{ }^{\circ} \mathrm{C}$ with constant shaking at $200 \mathrm{rpm}$ to an $\mathrm{OD}_{600}$ of 0.6. ZEN was dissolved in $70 \mathrm{mM}$ malonate buffer to $5 \mu \mathrm{g} / \mathrm{mL}$ supplemented with $1 \mathrm{mM} \mathrm{MnSO}$ and $0.1 \mathrm{mM} \mathrm{H}_{2} \mathrm{O}_{2}$. Twenty microliter of appropriately diluted ZEN pre-treated or non-treated with IlMnP5 or IlMnP6 were mixed with $200 \mu \mathrm{L}$ BLYES and the estrogenicity was checked by measuring the bioluminescence of the cells collected 6-h post treatment for analysis [20,21].

\subsection{Hydra Assay}

The hydra was maintained clean and free from bacteria and fungi contamination by treating with diluted iodine solution $(2.7 \mathrm{ppm})$ periodically. The assay was performed by exposing the hydra to $\mathrm{AFB}_{1}$ treated or nontreated with an MnP. Fifty $\mu \mathrm{g} / \mathrm{mL}$ of $\mathrm{AFB}_{1}$ were incubated with $I l \mathrm{MnP} 5$ or IlMnP6 (0.5 U/mL each) in $70 \mathrm{mM}$ malonate buffer supplemented with $1 \mathrm{mM} \mathrm{MnSO}_{4}$ and $0.1 \mathrm{mM} \mathrm{H}_{2} \mathrm{O}_{2}$. The reaction was carried out at $30^{\circ} \mathrm{C}$ for $10 \mathrm{~h}$. Each test dish contained $1 \mathrm{~mL}$ of test solution and three normal healthy hydra. The hydra were examined for signs of toxicity at $20 \mathrm{~h}$ and $40 \mathrm{~h}$, respectively. The toxic endpoint was determined by the "tulip" or "disintegration" stage of the hydra. In each test, experimental treatments were compared with untreated and solvent controls [19].

\subsection{HPLC and LC-MS/MS Analyses}

HPLC analysis of $\mathrm{AFB}_{1}, \mathrm{ZEN}$, DON, and OTA was performed using a SHIMADZU 20A series instrument (Kyoto, Japan) with an Agilent ZORBAX SB-C18 column $(5 \mu \mathrm{m}, 4.6 \mathrm{~mm} \times 250 \mathrm{~mm})$ (Santa Clara, CA, USA). The elution condition for $\mathrm{AFB}_{1}$ and $\mathrm{ZEN}$ was set as: no acetonitrile (ACN), 4 min; $0-100 \% \mathrm{ACN}, 25 \mathrm{~min} ; 100 \% \mathrm{ACN}, 6 \mathrm{~min}$, at a flow rate of $0.8 \mathrm{~mL} / \mathrm{min}$. $\mathrm{AFB}_{1}$ and $\mathrm{ZEN}$ were monitored at $365 \mathrm{~nm}$ or $316 \mathrm{~nm}$ [42], respectively. The elution condition for DON was set as: $20 \%$ methanol, $20 \mathrm{~min} ; 20-100 \%$ methanol, $1 \mathrm{~min} ; 100 \%$ methanol, $6 \mathrm{~min}$, at a flow rate of $0.8 \mathrm{~mL} / \mathrm{min}$. DON was monitored at $220 \mathrm{~nm}$. The mobile phase for OTA was mixed CAN: $\mathrm{H}_{2} \mathrm{O}: \mathrm{HAc}$ (99:99:2) and the flow rate was $1.0 \mathrm{~mL} / \mathrm{min}$. OTA was monitored for its absorbance at $333 \mathrm{~nm}$.

$\mathrm{AFB}_{1}, \mathrm{ZEN}$ transformation products were analyzed by using LC-MS/MS, which was carried out by coupling a SHIMADZU Nexera UHPLC system (Kyoto, Japan) to an AB-SCIEX 5600+ Triple TOF mass spectrometer (Waltham, Massachusetts, USA). The solvent A for LC is mixed ACN:methanol $(1: 1)$ and solvent $B$ is $0.1 \%$ fomic acid. The program was set as: $30-70 \%$ solvent $A, 10 \mathrm{~min} ; 70 \%$ solvent A, $8 \mathrm{~min} ; 100 \%$ solvent A, $2 \mathrm{~min} ; 30 \%$ solvent A, $5 \mathrm{~min}$. The parameters for MS analysis were: positive and high-sensitivity mode; GS1, 50 psi; GS2, 50 psi; curtain gas, 25 psi; temperature, $500{ }^{\circ} \mathrm{C}$; ion spray voltage floating, 5, $500 \mathrm{~V}$; $\mathrm{CE}$ energy, $35 \mathrm{~V} \pm 15 \mathrm{~V}$. Degradation of $\mathrm{FB}_{1}$ was analyzed by using UHPLC-MS/MS, which was carried out by the same method as above. 


\subsection{Phylogenetic Analysis}

The alignment of the amino acid sequences of $8 \mathrm{MnPs}$ were conducted using the clustalW algorithm of MEGA-X. Phylogenetic tree constructions were performed using the neighbor-joining method of MEGA-X. The reliability of the trees was tested by bootstrap analysis and the parameter was set to 1000. The other parameters used default values.

Supplementary Materials: Supplementary materials can be found at http://www.mdpi.com/2072-6651/11/10/566/ s1. Table S1: Primers used in this study. Figure S1: ZEN displays estrogenic activity on engineered S. cerevisiae BLYES. Figure S2: MS/MS spectrum of degradation products of $\mathrm{AFB}_{1}$ and ZEN. Figure S3: Purification of the recombinant MnPs. Figure S4: Time course analysis of degradation of four major mycotoxins by the eight MnPs. Figure S5: SOD and rutin suppressed RB5 decolorization with IlMnP5 and IlMnP6. Figure S6: Schematic drawing of recombinant plasmids for expressing MnPs.

Author Contributions: X.W. and X.Q. conducted experiments and wrote the manuscript. Z.H. and H.L. conducted experiments. B.Y. and X.S. conceived and designed the research. All authors contributed to data analyses, results interpretation.

Funding: This research was funded by the National Key R\&D Program of China [2016YFD050140902], the Chinese Academy of Agricultural Science and Technology Innovation Project [CAAS-XTCX2016011], the National Chicken Industry Technology System of China [CARS-41], and the Elite Youth Program of Chinese Academy of Agricultural Sciences.

Conflicts of Interest: The authors declare no conflict of interest.

\section{Abbreviations}

$\begin{array}{ll}\mathrm{AFB}_{1} & \text { Aflatoxin } \mathrm{B}_{1} \\ \mathrm{ZEN} & \text { Zearalenone } \\ \mathrm{DON} & \text { Deoxynivalenol } \\ \mathrm{FB}_{1} & \text { Fumonisin } \mathrm{B}_{1} \\ \mathrm{OTA} & \text { Ocharatoxin A } \\ \mathrm{IPTG} & \text { Isopropyl- } \beta \text {-D-thiogalactoside } \\ \text { ABTS } & \text { 2,2'-Azino-bis(3-ethylbenzothiazoline-6-sulphonic acid } \\ \mathrm{CAZy} & \text { Carbohydrate-Active enzyme } \\ \mathrm{AA} & \text { Auxiliary Activity } \\ \mathrm{MnP} & \text { Manganese Peroxidase } \\ \mathrm{GSH} & \text { Glutathione } \\ \mathrm{H}_{2} \mathrm{O}_{2} & \text { Hydrogen Peroxide }\end{array}$

\section{References}

1. Schatzmayr, G.; Streit, E. Global occurrence of mycotoxins in the food and feed chain: Facts and figures. World Mycotoxin J. 2013, 6, 213-222. [CrossRef]

2. Mitchell, N.J.; Bowers, E.; Hurburgh, C.; Wu, F. Potential economic losses to the US corn industry from aflatoxin contamination. Food Addit. Contam. A 2016, 33, 540-550. [CrossRef] [PubMed]

3. Galvano, F.; Piva, A.; Ritieni, A.; Galvano, G. Dietary strategies to counteract the effects of mycotoxins: A review. J. Food Protect. 2001, 64, 120-131. [CrossRef] [PubMed]

4. Motomura, M.; Toyomasu, T.; Mizuno, K.; Shinozawa, T. Purification and characterization of an aflatoxin degradation enzyme from Pleurotus ostreatus. Microbiol. Res. 2003, 158, 237-242. [CrossRef] [PubMed]

5. Engelhardt, G. Degradation of ochratoxin a and b by the white rot fungus Pleurotus ostreatus. Mycotoxin Res. 2002, 18, 37-43. [CrossRef] [PubMed]

6. Guan, S.; Ji, C.; Zhou, T.; Li, J.X.; Ma, Q.G.; Niu, T.G. Aflatoxin B(1) degradation by Stenotrophomonas maltophilia and other microbes selected using coumarin medium. Int J. Mol. Sci. 2008, 9, 1489-1503. [CrossRef] [PubMed]

7. Giardina, P.; Faraco, V.; Pezzella, C.; Piscitelli, A.; Vanhulle, S.; Sannia, G. Laccases: A never-ending story. Cell. Mol. Life Sci. 2010, 67, 369-385. [CrossRef] [PubMed]

8. Hofrichter, M. Review: Lignin conversion by manganese peroxidase (MnP). Enzyme Microb. Technol. 2002, 30, 454-466. [CrossRef] 
9. Alberts, J.F.; Gelderblom, W.C.A.; Botha, A.; Zyl, W.H.V. Degradation of aflatoxin B(1) by fungal laccase enzymes. Int. J. Food Microbiol. 2009, 135, 47-52. [CrossRef]

10. Yehia, R.S. Aflatoxin detoxification by manganese peroxidase purified from Pleurotus ostreatus. Braz. J. Microbiol. 2014, 45, 127-133. [CrossRef]

11. Wang, J.; Ogata, M.; Hirai, H.; Kawagishi, H. Detoxification of aflatoxin $B_{1}$ by manganese peroxidase from the white-rot fungus Phanerochaete sordida YK-624. FEMS Microbiol. Lett. 2011, 314, 164-169. [CrossRef]

12. Qin, X.; Sun, X.; Luo, H.; Ma, R.; Yao, B.; Ma, F. Deciphering lignocellulose deconstruction by the white rot fungus Irpex lacteus based on genomic and transcriptomic analyses. Biotechnol. Biofuels 2018, 11, 58. [CrossRef] [PubMed]

13. Qin, X.; Sun, X.; Huang, H.; Bai, Y.; Wang, Y.; Luo, H.; Yao, B.; Zhang, X.; Su, X. Oxidation of a non-phenolic lignin model compound by two Irpex lacteus manganese peroxidases: Evidence for implication of carboxylate and radicals. Biotechnol. Biofuels 2017, 10, 103. [CrossRef] [PubMed]

14. Martinez, A.T.; Speranza, M.; Ruiz-Duenas, F.J.; Ferreira, P.; Camarero, S.; Guillen, F.; Martinez, M.J.; Gutierrez, A.; del Rio, J.C. Biodegradation of lignocellulosics: Microbial, chemical, and enzymatic aspects of the fungal attack of lignin. Int. Microbiol. 2005, 8, 195-204. [PubMed]

15. Korripally, P.; Hunt, C.G.; Houtman, C.J.; Jones, D.C.; Kitin, P.J.; Cullen, D.; Hammel, K.E. Regulation of gene expression during the onset of ligninolytic oxidation by Phanerochaete chrysosporium on spruce wood. Appl. Environ. Microbiol. 2015, 81, 7802-7812. [CrossRef] [PubMed]

16. Fernandez-Fueyo, E.; Ruiz-Duenas, F.J.; Ferreira, P.; Floudas, D.; Hibbett, D.S.; Canessa, P.; Larrondo, L.F.; James, T.Y.; Seelenfreund, D.; Lobos, S.; et al. Comparative genomics of Ceriporiopsis subvermispora and Phanerochaete chrysosporium provide insight into selective ligninolysis. Proc. Natl. Acad. Sci. USA 2012, 109, 5458-5463. [CrossRef] [PubMed]

17. Banci, L.; Bertini, I.; Pease, E.A.; Tien, M.; Turano, P. Proton NMR investigation of manganese peroxidase from Phanerochaete chrysosporium. A comparison with other peroxidases. Biochemistry 1992, 31, 10009-100017. [CrossRef] [PubMed]

18. Mate, D.; Garcia-Burgos, C.; Garcia-Ruiz, E.; Ballesteros, A.O.; Camarero, S.; Alcalde, M. Laboratory evolution of high-redox potential laccases. Chem. Biol. 2010, 17, 1030-1041. [CrossRef] [PubMed]

19. McKenzie, K.S.; Sarr, A.B.; Mayura, K.; Bailey, R.H.; Miller, D.R.; Rogers, T.D.; Norred, W.P.; Voss, K.A.; Plattner, R.D.; Kubena, L.F.; et al. Oxidative degradation and detoxification of mycotoxins using a novel source of ozone. Food Chem. Toxicol. 1997, 35, 807-820. [CrossRef]

20. Sanseverino, J.; Gupta, R.K.; Layton, A.C.; Patterson, S.S.; Ripp, S.A.; Saidak, L.; Simpson, M.L.; Schultz, T.W.; Sayler, G.S. Use of Saccharomyces cerevisiae BLYES expressing bacterial bioluminescence for rapid, sensitive detection of estrogenic compounds. Appl. Environ. Microbiol. 2005, 71, 4455-4460. [CrossRef]

21. Krifaton, C.; Kriszt, B.; Risa, A.; Szoboszlay, S.; Cserhati, M.; Harkai, P.; Eldridge, M.; Wang, J.; Kukolya, J. Application of a yeast estrogen reporter system for screening zearalenone degrading microbes. J. Hazard. Mater. 2013, 244, 429-435. [CrossRef] [PubMed]

22. Wariishi, H.; Valli, K.; Gold, M.H. Manganese(II) oxidation by manganese peroxidase from the basidiomycete Phanerochaete chrysosporium. Kinetic mechanism and role of chelators. J. Biol. Chem. 1992, 267, 23688-23695. [PubMed]

23. Harazono, K.; Watanabe, Y.; Nakamura, K. Decolorization of azo dye by the white-rot basidiomycete Phanerochaete sordida and by its manganese peroxidase. J. Biosci. Bioeng. 2003, 95, 455-459. [CrossRef]

24. Sawa, T.; Nakao, M.; Akaike, T.; Ono, K.; Maeda, H. Alkylperoxyl radical-scavenging activity of various flavonoids and other phenolic compounds: Implications for the anti-tumor-promoter effect of vegetables. J. Agric. Food Chem. 1999, 47, 397-402. [CrossRef] [PubMed]

25. Gu, L.; Lajoie, C.; Kelly, C. Expression of a Phanerochaete chrysosporium manganese peroxidase gene in the yeast Pichia pastoris. Biotechnol Prog. 2003, 19, 1403-1409. [CrossRef] [PubMed]

26. Lin, M.-I.; Nagata, T.; Katahira, M. High yield production of fungal manganese peroxidases by E. coli through soluble expression, and examination of the activities. Protein Expr. Purif. 2018, 145, 45-52. [CrossRef]

27. Zhang, H.; Zhang, S.; He, F.; Qin, X.; Zhang, X.; Yang, Y. Characterization of a manganese peroxidase from white-rot fungus Trametes sp.48424 with strong ability of degrading different types of dyes and polycyclic aromatic hydrocarbons. J. Hazard. Mater. 2016, 320, 265-277. [CrossRef] [PubMed]

28. Broom, L. Mycotoxins and the intestine. Anim. Nutr. 2015, 1, 262-265. [CrossRef] [PubMed] 
29. Guengerich, F.P.; Johnson, W.W. Kinetics of hydrolysis and reaction of aflatoxin $\mathrm{B}_{1}$ exo-8,9-epoxide and relevance to toxicity and detoxication. Drug Metab. Rev. 1999, 31, 141-158. [CrossRef] [PubMed]

30. Engina, A.B.; Engin, A. DNA damage checkpoint response to aflatoxin $B_{1}$. Environ. Toxicol. Pharmacol. 2019, 65, 90-96. [CrossRef] [PubMed]

31. Marchese, S.; Polo, A.; Ariano, A.; Velotto, S.; Costantini, S.; Severino, L. Aflatoxin $B_{1}$ and $M_{1}$ : Biological properties and their involvement in cancer development. Toxins 2018, 10, 214. [CrossRef]

32. Loi, M.; Fanelli, F.; Cimmarusti, M.T.; Mirabelli, V.; Haidukowski, M.; Logrieco, A.F.; Caliandro, R.; Mule, G. In vitro single and combined mycotoxins degradation by Ery4 laccase from Pleurotus eryngii and redox mediators. Food Control 2018, 90, 401-406. [CrossRef]

33. Lombard, V.; Golaconda Ramulu, H.; Drula, E.; Coutinho, P.M.; Henrissat, B. The carbohydrate-active enzymes database (CAZy) in 2013. Nucleic Acids Res. 2014, 42, D490-D495. [CrossRef] [PubMed]

34. Hori, C.; Gaskell, J.; Igarashi, K.; Kersten, P.; Mozuch, M.; Samejima, M.; Cullen, D. Temporal alterations in the secretome of the selective ligninolytic fungus Ceriporiopsis subvermispora during growth on aspen wood reveal this organism's strategy for degrading lignocellulose. Appl. Environ. Microbiol. 2014, 80, 2062-2070. [CrossRef] [PubMed]

35. Jiang, F.; Kongsaeree, P.; Charron, R.; Lajoie, C.; Xu, H.; Scott, G.; Kelly, C. Production and separation of manganese peroxidase from heme amended yeast cultures. Biotechnol. Bioeng. 2008, 99, 540-549. [CrossRef] [PubMed]

36. Conesa, A.; Jeenes, D.; Archer, D.B.; van den Hondel, C.A.; Punt, P.J. Calnexin overexpression increases manganese peroxidase production in Aspergillus niger. Appl. Environ. Microbiol. 2002, 68, 846-851. [CrossRef] [PubMed]

37. Loi, M.; Fanelli, F.; Zucca, P.; Liuzzi, V.C.; Quintieri, L.; Cimmarusti, M.T.; Monaci, L.; Haidukowski, M.; Logrieco, A.F.; Sanjust, E.; et al. Aflatoxin $\mathrm{B}_{1}$ and $\mathrm{M}_{1}$ degradation by Lac2 from Pleurotus pulmonarius and redox mediators. Toxins 2016, 8, 245. [CrossRef]

38. Morozova, O.V.; Shumakovich, G.P.; Shleev, S.V.; Iaropolov, A.I. Laccase-mediator systems and their applications: A review. Appl. Biochem. Microbiol. 2007, 43, 523-535. [CrossRef]

39. Sundaramoorthy, M.; Kishi, K.; Gold, M.H.; Poulos, T.L. Preliminary crystallographic analysis of manganese peroxidase from Phanerochaete chrysosporium. J. Mol. Biol. 1994, 238, 845-848. [CrossRef]

40. Sundaramoorthy, M.; Youngs, H.L.; Gold, M.H.; Poulos, T.L. High-resolution crystal structure of manganese peroxidase: Substrate and inhibitor complexes. Biochemistry 2005, 44, 6463-6470. [CrossRef]

41. Fernandez-Fueyo, E.; Acebes, S.; Ruiz-Duenas, F.J.; Martinez, M.J.; Romero, A.; Medrano, F.J.; Guallar, V.; Martinez, A.T. Structural implications of the C-terminal tail in the catalytic and stability properties of manganese peroxidases from ligninolytic fungi. Acta Crystallogr. D 2014, 70, 3253-3265. [CrossRef] [PubMed]

42. Briones-Reyes, D.; Gomez-Martinez, L.; Cueva-Rolon, R. Zearalenone contamination in corn for human consumption in the state of Tlaxcala, Mexico. Food Chem. 2007, 100, 693-698. [CrossRef] 